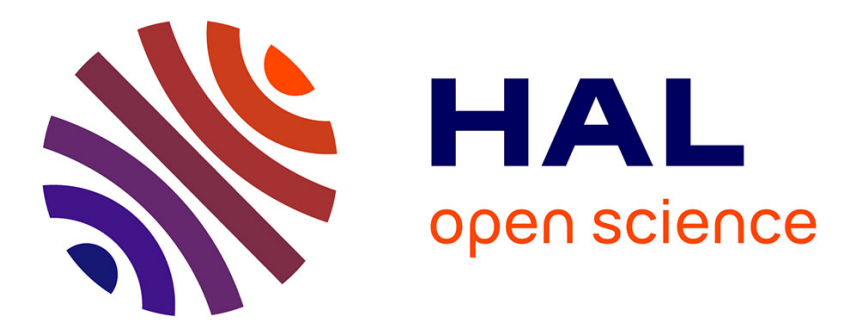

\title{
Electrophoresis-assisted accumulation of conductive nanoparticles for the enhancement of cell electropermeabilization
}

Amina Ghorbel, Franck M. André, Lluis M. Mir, Tomas Garcia-Sanchez

\section{To cite this version:}

Amina Ghorbel, Franck M. André, Lluis M. Mir, Tomas Garcia-Sanchez. Electrophoresis-assisted accumulation of conductive nanoparticles for the enhancement of cell electropermeabilization. Bioelectrochemistry, 2021, 137, pp.107642. 10.1016/j.bioelechem.2020.107642 . hal-03087913

\section{HAL Id: hal-03087913 \\ https://hal.science/hal-03087913}

Submitted on 29 Nov 2021

HAL is a multi-disciplinary open access archive for the deposit and dissemination of scientific research documents, whether they are published or not. The documents may come from teaching and research institutions in France or abroad, or from public or private research centers.
L'archive ouverte pluridisciplinaire HAL, est destinée au dépôt et à la diffusion de documents scientifiques de niveau recherche, publiés ou non, émanant des établissements d'enseignement et de recherche français ou étrangers, des laboratoires publics ou privés. 


\title{
Electrophoresis-assisted accumulation of conductive nanoparticles for the enhancement of cell electropermeabilization
}

\author{
Amina Ghorbel ${ }^{1}$, Franck M. André1 ${ }^{1}$, Lluis M. Mir1", Tomás García-Sánchez ${ }^{1,2}$ \\ 1 Université Paris-Saclay, CNRS, Institut Gustave Roussy, Metabolic and systemic aspects of \\ oncogenesis (METSY), 94805, Villejuif, France \\ 2Department of Information and Communication Technologies, Universitat Pompeu Fabra. Roc \\ Boronat, 138, 08018 Barcelona, Spain \\ \# Lluis M. Mir https://orcid.org/0000-0002-8671-9467 email: luis.mir@cnrs.fr \\ \# Tomás García-Sánchez https://orcid.org/0000-0002-1115-0683 email: tomas.garcia@upf.edu
}

\begin{abstract}
The use of conductive nanoparticles (NPs) was previously proposed as a way to locally amplify the electric field (EF) intensity at the cell membrane to enhance cell electroporation. To achieve this, a close distance between the NPs and the cell membrane is mandatory. Here, a new method to improve the contact between NPs and cell surface using the effects of electric pulses (electrophoretic forces) is explored. The effects of two types of electric pulses are analyzed alone or combined in a two-pulse-train protocol on Chinese hamster DC-3F cells. Particularly we used $100 \mu$ s duration pulses, low intensitymillisecond pulses and combinations of both. Finally, we studied the use of surface coated NPs (PEGylated) for this application. Our results demonstrate that the delivery of an electric field prior to the electroporation pulses increases the accumulation of NPs around the cell membrane suggesting that NPs are pushed towards the cell surface through electrophoretic forces. This allowed reducing the need for long incubations between cells and NPs to observe an enhancement of electroporation mediated by conductive NPs. Thus low intensity-millisecond pulses can be used to increase the accumulation of either aggregated or individual (i.e. PEGylated) NPs supporting the electrophoretic nature of the observed effects.
\end{abstract}

Keywords: gold nanoparticles, local electric field, pulsed electric fields, electroporation.

\section{${ }^{*}$ Corresponding author:}

Email: luis.mir@cnrs.fr

Telephone number: +33142114792

Address: UMR 9018 CNRS, Gustave Roussy PR2, 114 rue E. Vaillant, 94805 Villejuif, Cédex.

Abbreviations: DC-3F: a Chinese hamster lung cell line; EF, electric field; NPs, nanoparticles; GNPs, gold nanoparticles; PDMS, Polydimethylsiloxane; PEG, poly(ethylene glycol) methyl ether thiol; PEGGNPs, PEGylated surface coated GNPs; ECT, electrochemotherapy; PEFs, pulsed electric fields; $\mu \mathrm{sPEFs}$, microsecond pulsed electric fields; msPEFs, millisecond pulsed electric fields; MEM, minimum essential mediumDLS, dynamic light scattering; TEM, transmission electron microscopy. 


\section{Introduction}

Over the past decades, nanoparticles (NPs) have emerged as promising tools, in several biomedical applications, such as drug nanocarriers[1-3] or as theranostics agents [4-8]. Based on their electrical properties, NPs can be classified into two categories: conductive NPs and non-conductive NPs. Nonconductive NPs which are mainly organic NPs (e.g. liposomes or polymers-based NPs) are known for their biocompatibility and biodegradability, constituting the most widely used NPs in drug delivery systems, especially to treat cancer[9]. Non-conductive NPs can also be inorganic NPs (e.g. silica NPs) which are used as gene transfection carriers and controlled release drug delivery systems for several biomedical applications[10]. Regarding conductive NPs, they can be inorganic or organic (e.g. PEDOT polymer-made[11]) NPs. Conductive NPs, in particular gold NPs (GNPs), were successfully explored in recent decades in the field of medicine, particularly for cancer treatment. Indeed, gold NPs have gained the attention of many researchers by their ability to be used as contrast agents in X-ray medical imaging [12] and as radioenhancement agents [13] to kill cancer cells. Moreover, GNPs were also used to treat cancer by photo-thermal therapy using NPs able to absorb near-infrared light to kill cancer cells by the heat generated from the NPs illumination[14]. Based on their high conductivity and their reduced toxicity [15] compared to others conductive materials, GNPs were used in our previous[16] work to investigate their potential for enhancing the efficiency of electroporation in vitro.

Electroporation or electropermeabilization, is defined as the permeabilization of the cell membrane induced by the exposure of the cells to short and intense electric field pulses [17]. Therefore, a considerable increase in the transport of ions and molecules (e.g. drugs) across the cell membrane is generated $[18,19]$.Based on electroporation, antitumor electrochemotherapy (ECT) represents the most successful clinical application of electroporation. This treatment consists in the application to the tumors of a small number ( 4 to 8 ) of intense electric field pulses (with an intensity between1000 to 1300 V.cm ${ }^{-1}$ ) combined with the administration of a non-/low-permeant anticancer drug (e.g. bleomycin [20] or cisplatin). Interestingly, not only drugs can be transferred into target cells but also macromolecules (e.g. nucleic acids). In the case of the transfer of charged macromolecules (e.g. DNA) using electric fields (EF), not only electroporation is involved but also electrophoresis [21]. The electrophoresis phenomenon can be easily combined with cell electroporation, using thus two types of electric pulses, in order to control the permeabilization of the cells at the first stage (one or several electroporative pulses) and then to control the transport of the charged molecules toward or across the permeabilized 
membrane (one or several electrophoretic pulses). This technique was successfully applied in vitro [21] as well as in vivo [22,23].

The concept of combining electroporation with conductive NPs to amplify locally the electric field, has been tested in few recent studies. Conductive NPs other than GNPs were tested for irreversible ([24] or reversible [25] electroporation. GNPs were also used in combination with electric pulses to improve gene electrotransfer $([26,27]$ Our previous work in vitro [16] clearly showed an enhancement of the electroporation outcome likely due to local amplification of the external EF mediated by conductive NPs (not only GNPs but also Platinum NPs) present near the cell membrane, allowing thus for a reduction of the applied voltage. However, to obtain a significant enhancement of the EF effects compared to the case without conductive NPs, cells had to be incubated with the conductive NPs for a rather long time (3 h) at $4^{\circ} \mathrm{C}$ (in order to avoid the endocytosis). This enhancement was not statistically significant when the incubation lasted for only $1 \mathrm{~h}$. The need for a long incubation is probably linked to the mechanism operating in the transport of the NPs to the close vicinity of the cell membrane, that is merely the physical sedimentation of the NPs at the surface of the attached cells. This sedimentation aspect also seemed to be a limiting approach to translate our in-vitro results to in-vivo studies. Therefore, the optimization of the interaction of the NPs with the cells seemed interesting to go further after the proof of concept previously reported [16].

The mechanisms involved in the amplification of the EF by conductive NPs are not yet clear, but our previous observations revealed the importance of the physical contact/distance and distribution of conductive NPs close to (in contact with) the cell membrane to achieve the local amplification of the applied electric field. Based on these previous observations and requests for efficacy, we elaborated the hypothesis that electrophoretic pulses could displace conductive NPs towards cell membrane, concentrating them near the membrane and even increasing the physical contact (reducing the distance) between the NPs and the cell membrane. These electrophoretic pulses should result in a further enhancement of the electroporation efficiency of classical microsecond electric pulses in the presence of conductive NPs. Thus, in this study we explored the possibility of using electrophoresis to effectively bring the GNPs at the cell surface, thus reducing the incubation time needed to observe a significant effect of NPs on cell electroporation enhancement. Moreover, to avoid NPs aggregation, a polymerbased surface coating of GNPs was used and the effects of coated GNPs alone or in combination with electrophoretic pulses were explored to enhance electroporation. 


\section{Materials and Methods}

\subsection{Cell culture}

Chinese hamster lung cell line (DC-3F) was grown and maintained as a monolayer in MEM-Minimum Essential Medium (Life Technologies, Saint-Aubin, France) supplemented with 10\% fetal bovine serum (Life Technologies) and $1 \%$ penicillin-streptomycin at $37^{\circ} \mathrm{C}$ and $5 \% \mathrm{CO}_{2}$ and was routinely sub-cultured every two days. For the experiments, $600 \mu \mathrm{l}$ of cells at a density of $1.3^{*} 10^{5} \mathrm{cells} / \mathrm{ml}$ were seeded in a 35 $\mathrm{mm}$ Petri dish in which a rectangular bottomless chamber made of PDMS (Polydimethylsiloxane) limited to $2 \mathrm{~cm}^{2}$ the area offered to the cell culture[16]. Cells were then grown for $24 \mathrm{~h}$, until they reached about $80 \%$ confluence, and they were treated as described below.

\subsection{Gold nanoparticles}

Gold nanoparticles (GNPs) with an average size of $40 \mathrm{~nm}$ in citrated water $(741981-100 \mathrm{ml}$, SigmaAldrich, St. Quentin Fallavier, France) were used at a working concentration of $50 \mu \mathrm{g} \cdot \mathrm{ml}^{-1}$. The GNPs solution was concentrated (5X) by centrifugation at $11000 \mathrm{rpm}$ for $10 \mathrm{~min}$ (Eppendorf centrifuge, model 5810R) to remove most of the citrate buffer and decrease the possible effects of this buffer on the cells during the exposure to the electric fields. GNPs were re-suspended in serum-free MEM and sonicated for 10 min at $25^{\circ} \mathrm{C}$ (Ultrasonic Cleaner model VWR 300D at maximum power) before adding them to the cells. Conductivity measurements of the medium with and without the GNPs were performed using a FiveEasy FE30 conductivity meter (Mettler-Toledo, Schwerzenbach, Switzerland).

\subsection{Pegylation of Gold nanoparticles}

Poly(ethylene glycol) methyl ether thiol (PEG) of average molecular weight MW 6000 Daltons was purchased from Sigma-Aldrich (729159-1G). In order to produce PEG-capped GNPs, $60 \mu L$ of the PEG stock solution $(4 \mathrm{mg} / \mathrm{ml})$ were added to citrate-capped GNPs $(3 \mathrm{~mL})$ to reach the final PEG concentration of $80 \mu \mathrm{g} \cdot \mathrm{ml}^{-1}$. The solution was then stirred for $1 \mathrm{~h}$ at room temperature to allow the covalent grafting of PEG on the GNPs surface (exchange of the citrate molecules with PEG[28]). The resulting PEG-coated GNPs were then rinsed with $7 \mathrm{~mL}$ of distilled water and centrifuged at $11,000 \mathrm{rpm}$ for $15 \mathrm{~min}$. Subsequently, the supernatant was removed and the pellet (containing the PEG coated GNPs) was rinsed again with distilled water. This washing procedure was repeated twice to remove the excess of PEG molecules[28-30]. Finally, the obtained PEG-coated GNPs (PEG-GNPs) were re-suspended in 
serum-free MEM and sonicated for $10 \mathrm{~min}$ at $25^{\circ} \mathrm{C}$ (Ultrasonic Cleaner model VWR 300D at maximum power) before adding them to the cells at $50 \mu \mathrm{g} \cdot \mathrm{ml}^{-1}$.

\subsection{Characterization of NPs suspensions by Dynamic light scattering (DLS)}

The average effective diameters and the zeta-potential of the colloidal NPs suspensions used in the experiments were measured by Dynamic Light Scattering (DLS) (Brookhaven, Nanobrook 90plus PALS). To retrieve information about the size of NPs in the culture medium, GNPs and PEG-GNPs were re-suspended in serum-free MEM culture medium, sonicated (as described in Gold nanoparticles section) and at least three measurements were independently taken for each sample. Here, it is noteworthy to mention that citrate buffer acts as a stabilizing agent by forming a layer of citrate ions over the surface of GNPs, inducing enough electrostatic repulsion between individual particles to keep them dispersed in the medium thus preventing their aggregation. However, the culture medium used is composed of a high concentration of ions (i.e. high ionic strength in the presence of bio macromolecules). Hence, a comparison between the DLS profiles of GNPs in their commercial buffer (citrated buffer) and GNPs and PEG-GNPs in serum-free culture medium was performed. Furthermore, to have an idea about the charge of the used NPs, zeta-potential measurements were also performed for GNPs and PEG-GNPs. For the measurement, samples already prepared in the serum free-medium (as described above) were diluted with distilled water. All measurements were carried out in triplicate.

\subsection{Electropulsation setup}

Two types of pulsed electric fields (PEFs) were delivered to the cells; they were classified as long duration PEFs (millisecond time scale; msPEFs, also termed here as LV) and short duration PEFs (microsecond time scale; $\mu \mathrm{SPEFs}$, also termed here as HV). Specially adapted electrodes (two stainless steel parallel plates distant of $0.6 \mathrm{~cm}$ ) were used to expose the entire monolayer to the electric pulses.

For the $\mu \mathrm{sPEFs}$, the electrodes were connected to a Cliniporator ${ }^{\mathrm{TM}}$ (IGEA, Carpi, Italy), which delivered eight short electric pulses of $100 \mu \mathrm{s}$ duration at a fixed voltage of $360 \mathrm{~V}$ (resulting in an electric field intensity of $600 \mathrm{~V} . \mathrm{cm}^{-1}$ ) and repetition rate of $1 \mathrm{~Hz}$.

For the msPEFs, using the same experimental setup, electrodes were connected to an AFG 3251 TEKTRONIX generator which delivered one long electric pulse of $400 \mathrm{~ms}$ duration at a fixed voltage of $3 \mathrm{~V}$ (resulting in an electric field intensity of $\left.5 \mathrm{~V} . \mathrm{cm}^{-1}\right)$. This electric field intensity was chosen to ensure 
the absence of electropermeabilization by this pulse alone (this was verified using yo-pro- 1 and flow cytometry) (Data not shown).

\subsection{Electropermeabilization assessment via clonogenic assay}

Electropermeabilization of living cells was determined by means of a clonogenic assay using bleomycin. Adherent cells were washed with phosphate buffered saline and the NPs solution was added to the cell monolayer. In order to let the NPs go towards the cells surface, a first incubation of the attached cells with the NPs for $1 \mathrm{~h}$ at $4^{\circ} \mathrm{C}$ was performed under all conditions. Thereafter, after $5 \mathrm{~min}$ at room temperature, electrodes were placed and cells were submitted to the corresponding electric field. For the double pulse sequences, first one msPEF of 400 ms duration or eight $\mu \mathrm{sPEFs}$ of $100 \mu \mathrm{s}$ duration were applied. If applicable, eight minutes later, $50 \mu \mathrm{l}$ of bleomycin were added to the $600 \mu \mathrm{l}$ of medium to reach a final concentration of $30 \mathrm{nM}$ and two minutes later, cells were pulsed again using eight $\mu \mathrm{SPEFs}$ of $100 \mu$ s duration. Ten minutes after the second pulse train, electrodes were removed and cells were washed once with PBS, detached with TrypLE Express (Life Technologies), suspended in medium, counted and diluted in order to deposit 250 cells per well of a six-multiwell plate (three wells per experimental condition). Non-pulsed cells used as controls were handled similarly. After 5 days of culture, cells were washed twice, fixed with crystal violet solution $(0.2 \%$ Crystal Violet, $10 \%$ formaldehyde and $20 \%$ ethanol in $\mathrm{H}_{2} \mathrm{O}$ ), and the stained colonies were counted. For each treatment condition, the viability rate of the treated cells was reported, in percentage, to the viability rate of the non-pulsed cells. In each experiment, each condition was independently repeated three times, and experiments were repeated three times in different days. Two-way ANOVA followed by Tukey multiple comparisons test were used to determine the significance of the differences.

\subsection{Transmission Electron Microscopy (TEM) procedures}

To study the exact location of the nanoparticles with respect to the cell membranes, we performed TEM microscopy. Immediately after each particular NPs-cell interaction condition, glutaraldehyde $25 \%$ was added over the cell monolayer, without any previous aspiration of the medium, in amounts allowing to reach a final concentration of about $2 \%-2.5 \%$. The first step of the fixation procedure was therefore in the complete medium with $10 \%$ FCS, with minimal perturbation of the cells and NPs. Then medium was removed and $0.1 \mathrm{M}$ Sorënsen's phosphate buffer $(\mathrm{pH} 7.3)$ with $2 \%$ glutaraldehyde 
was slowly and carefully added, and the attached cells fixed for 1 hat $4^{\circ} \mathrm{C}$, post-fixed with $2 \%$ osmic acid at room temperature for $1 \mathrm{~h}$, rinsed in water and dehydrated in a grade ethanol series in situ. Cell monolayers were embedded on the surface of inverted Epon812-filled capsules. Polymerization was complete after $48 \mathrm{~h}$ at $60^{\circ} \mathrm{C}$. Ultra-thin sections were collected on 200 mesh grids coated with Formvar and carbon, stained with standard uranyl acetate and lead citrate before observation with a Tecnai 12 electron microscope (FEI, Eindhoven, Netherlands). Digital images were taken with a SIS Megaview III CCD camera (Olympus, Tokyo, Japan).

\subsection{Counting and localization of GNPS/ GNPs-aggregates with respect to the cell membrane}

GNPs/GNPs-aggregates around cells were counted in the TEM images to better understand the mechanisms of the NPs effects. We categorized GNPs/GNPs-aggregates by their size and by their distance with respect to the cell membrane. This characterization was made considering the whole of the GNPs/ GNPs-aggregates present in each TEM image. At least 20 images were analyzed per condition. The number of GNPs/GNPs-aggregates were normalized with respect to the number of cells in the sections analyzed. Each TEM image depicted at least one cell. Thus, at least twenty cells randomly chosen were counted per experimental condition.

The size distribution of the GNPs-aggregates was classified in four groups: large aggregates of more than 20 GNPs, intermediate aggregates of 10 to 20 GNPs, small aggregates of 5 to 10 GNPs, and the "NPs" corresponding to the smallest aggregates, between 1 and 5 GNPs. The distance of GNPs to the cell membrane was categorized into three ranges of distance: "Close" corresponds to GNPs in contact with the cell membrane, "Intermediate distance" to GNPs that were at the surface but not in contact with the cell membrane and "Far" to GNPs which were far from the surfaces.

\section{Results}

\subsection{Changes in gold nanoparticles distribution around cell membrane after electric field exposure}

In our previous article [16], the accumulation of conductive GNPs (or Platinum-NPs) at the cell membrane of attached cells was performed by incubating the NPs with cells at $4^{\circ} \mathrm{C}$ (in order to prevent cell endocytosis and NPs engulfment, thus leaving the NPs at the cell surface) for different durations. We showed an improved accumulation of GNPs and the corresponding enhancement of electroporation 
outcome with longer incubation time ( $1 \mathrm{~h}$ versus $3 \mathrm{~h}$ ), likely produced by an increased sedimentation of NPs. In order to understand better the mechanisms involved in this enhancement of electroporation by GNPs accumulation, we explored by TEM the NPs distribution around the cells before and after the electric pulses delivery. Fig 1 corresponds to representative TEM images of GNPs incubated for $1 \mathrm{~h}$ at $4^{\circ} \mathrm{C}$ before (Fig. 1a) and after (Fig. 1b) a single sequence of eight pulses of $100 \mu$ s at $600 \mathrm{~V} . c m^{-1}$

As reported in our previous study Fig. 1a shows a poor accumulation of GNPs at the cell surface after the incubation for $1 \mathrm{~h}$. Surprisingly, when TEM imaging was performed after the application of the pulses in the presence of GNPs (already incubated for $1 \mathrm{~h}$ at $4^{\circ} \mathrm{C}$ ), a remarkable increase in the number of GNPs-aggregates was observed at the cell surface (Fig 1b). Moreover, in this case, GNPs seemed to be very close to the cell membrane suggesting that the pulse application approaches the GNPs to the cells and might enhance the interaction of the GNPs with the cells.
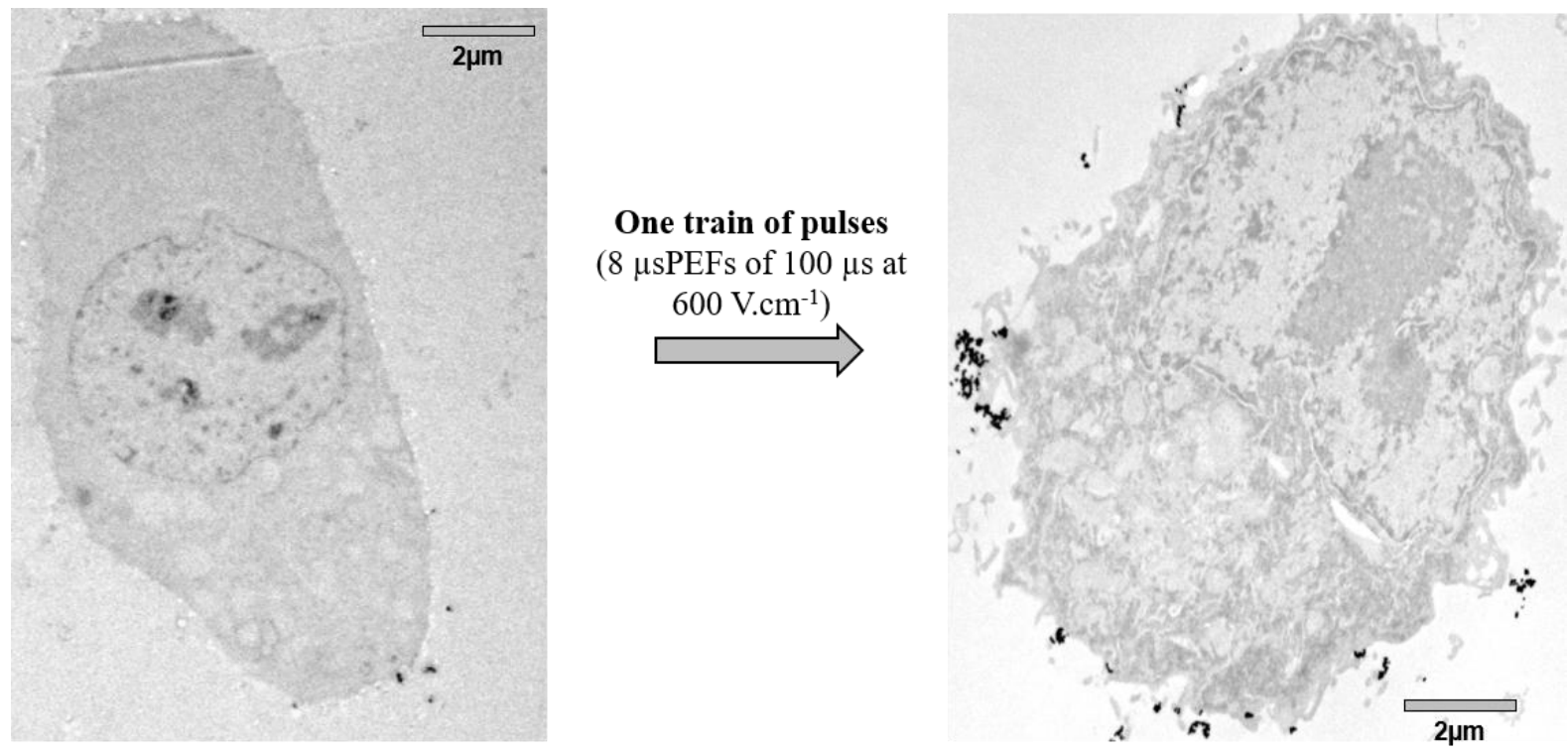

Fig. 1: a) Representative TEM image of an attached cell incubated with the GNPs during $1 \mathrm{~h}$ at $4^{\circ} \mathrm{C}$. b) Representative TEM image of an attached cell incubated with GNPs during $1 \mathrm{~h}$ at $4^{\circ} \mathrm{C}$ and then pulsed using eight $\mu$ sPEFs of $100 \mu \mathrm{s}$.

\subsection{Effect of repeated application of microsecond pulses on GNPs-cells contact}


Driven by the observation reported in the previous section, we decided to perform a series of experiments where the attached cells already in contact with GNPs for $1 \mathrm{~h}$ at $4^{\circ} \mathrm{C}$ were submitted to two trains of pulses: a first train of eight $\mu \mathrm{sPEFs}$ of $100 \mu \mathrm{s}$ without bleomycin to improve cell membraneGNP contact, and 10 minutes later, a second train of pulses of the same characteristics in the presence of bleomycin to test whether the cell electropermeabilization level was enhanced by the increase of the GNPs-cell monolayer contact. The cell electropermeabilization level was quantified using bleomycin as a permeabilization marker that was added to the cells eight minutes after the first train of pulses. This delay was selected since preliminary experiment (data not shown) showed that it was sufficient for cells to reseal from the first train of pulses. Results in the presence or not of GNPs were compared. It is worth mentioning that conductivity of the medium $(13.1 \pm 0.2 \mathrm{mS} / \mathrm{cm} \mathrm{cm}$ in the absence of the GNPs) was not affected by the presence of the GNPs $(13.2 \pm 0.4 \mathrm{mS} / \mathrm{cm}$ with the GNPs at the concentrations used here).

Fig. 2 shows that in the absence of bleomycin, the exposure of the cell monolayer to two trains of eight MSPEFs of $100 \mu$ s resulted in about $15 \%$ of cell death without significant differences between the conditions with or without GNPs. This effect could be explained by a certain level of irreversible electroporation or other electrochemical effects on the cells near the electrodes. Thus, we can conclude that neither the application of two trains of pulses nor a potentially strong accumulation of GNPs at the surface of the cell membrane (Fig.1b) lead to a significant increase in cell death. However, by adding 
bleomycin during the second pulse sequence, the combination of two trains of $\mu$ SPEFs with GNPs significantly increased the effect of the $\mu$ SPEFs by about $20 \%$ compared to the case without GNPs.

In our previous study [16], pulsing the cells in the presence of bleomycin after the incubation of the cells with GNPs for only $1 \mathrm{~h}$ at $4^{\circ} \mathrm{C}$ resulted in a slight and non-significant increase of the electric field effects by around $10 \%$. Compared to this result here we show that the combination of the two pulseslsequences significantly increases the effect to $20 \%$. This increase is similar to the effect achieved when GNPs were incubated with cells for $3 \mathrm{~h}$ at $4^{\circ} \mathrm{C}$ as also reported in [16]. Thus, the improved interaction of GNPs

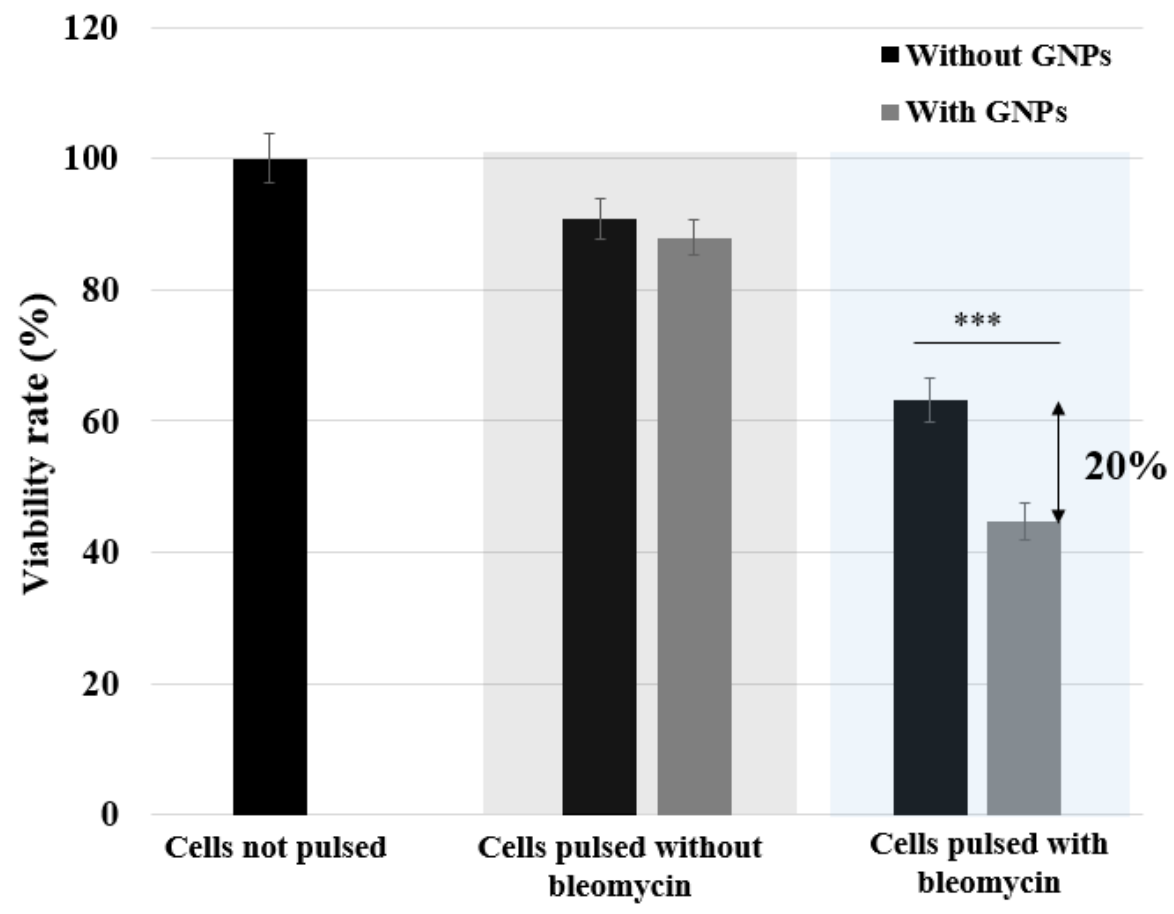

Figure 2: Clonogenic assay: Repeated pulse treatment of cells with two trains of eight $\mu \mathrm{SPEFs}$ of $100 \mu \mathrm{s}$ applied in combination (or not) with bleomycin in the presence (or not) of GNPs previously incubated with the cells for $1 \mathrm{~h}$ at $4^{\circ} \mathrm{C}$. The error bars correspond to \pm the standard deviation. Experiments were performed in three independent days and each one included a triplicate for each condition.

and cell membrane produced by a first sequence of electric pulses enhances the effectiveness of the $\mu \mathrm{SPEFs}$ and is an efficient way to minimize the need of a long incubation period of cells with NPs.

\subsection{Use of non-permeabilizing, low amplitude and long duration PEFs}

The application of two consecutive sequences of permeabilizing pulses could induce possible biases in the interpretation of the previous result mainly due to the previously reported sensitization and desensitization effects[32]-[33]. Thus, we explored if the observed improvement in cell electroporation 
could be reproduced using one low amplitude, long duration, non-permeabilizing electric pulse (one msPEF) to drive the GNPs close to the cell membrane. The second train of eight $\mu \mathrm{SPEFs}$ of $100 \mu \mathrm{s}$ was maintained to cause the electropermeabilization of the cell membrane and analyze the GNPs effects. Therefore, attached DC-3F cells were similarly incubated for $1 \mathrm{~h}$ at $4^{\circ} \mathrm{C}$ and exposed to the two different trains of pulses, first the msPEF and then the $\mu \mathrm{SPEFs}$. Based on our large previous experience on the duration of electrophoretic pulses (mainly delivered in vivo after the electroporating pulses, with the aim to bring nucleic acids close to the electroporated membrane and to achieve a huge increase in the yield of the nucleic acids electrotransfer), we decided to use here PEFs of $400 \mathrm{~ms}$ that are long but, still, just electrophoretic (no electroporation at all by themselves) and not deleterious for the cells. As for the amplitude of the electric field, in our experimental setting, it was determined in a series of preliminary experiments using Yo-Pro-and flow cytometry. While one pulse of $10 \mathrm{~V}\left(16.6 \mathrm{~V} . \mathrm{cm}^{-1}\right)$ and $5 \mathrm{~V}\left(8.3 \mathrm{~V} . \mathrm{cm}^{-}\right.$ $\left.{ }^{1}\right)$ were causing some cell permeabilization, one pulse of $400 \mathrm{~ms}$ and $4 \mathrm{~V}\left(6.6 \mathrm{~V} . \mathrm{cm}^{-1}\right)$ or $3 \mathrm{~V}\left(5 \mathrm{~V} . \mathrm{cm}^{-1}\right)$ did not electroporate the cells. We decided to apply $5 \mathrm{~V} . \mathrm{cm}^{-1}$ in order to have a security margin and be sure that no electroporation is caused by the $400 \mathrm{~ms}$ electrophoretic pulse. Thus, in the experiments reported in Fig 2, the first train of eight $\mu$ SPEFs of $100 \mu$ s was replaced by a single msPEF of $400 \mathrm{~ms}$ and $5 \mathrm{~V} . \mathrm{cm}^{-1}$ in the absence of bleomycin. Then bleomycin was added and the second train of pulses was applied.

TEM imaging was performed to localize the GNPs after each treatment. Fig. 3a shows respectively cells incubated with GNPs for $1 \mathrm{~h}$ at $4^{\circ} \mathrm{C}$ either not pulsed (left panel) or pulsed only with one msPEF (400 $\mathrm{ms}$ at $5 \mathrm{~V} . \mathrm{cm}^{-1}$ ) (middle panel) or pulsed with both one msPEF followed by the $\mu \mathrm{SPEFs}$ (after $10 \mathrm{~min}$ ) (right panel). After the sole incubation of the GNPs with cells for $1 \mathrm{~h}$ at $4^{\circ} \mathrm{C}$, TEM images confirm again that a reduced number of GNPs-aggregates were around the cell membrane and poorly in contact with its surface. By applying one msPEF of $400 \mathrm{~ms}$ or the two-pulse sequence, there are noticeable differences in the number and distance of the GNPs-aggregates around the cell surface compared to the incubation only condition. The table presented in Fig 3b displays the number of GNPs aggregates normalized with respect to the number of cells in the sections analyzed for the different conditions according to the classifications explained in Materials and Methods. There are noticeable changes caused by the mSPEF or the combined msPEF plus $\mu \mathrm{sPEFs}$ in the number and localization of the GNPsaggregates of different sizes. First, for these two conditions, overall, the number of GNPs increased 
a)

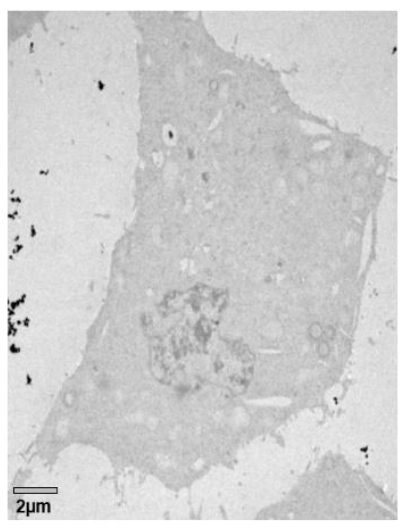

$1 \mathrm{~h}$ at $4^{\circ} \mathrm{C}$

(No pulse)

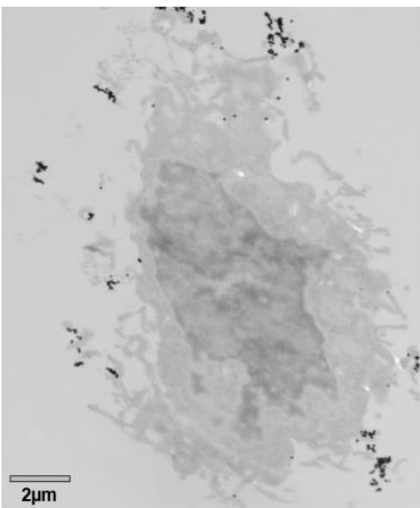

$1 \mathrm{~h}$ at $4^{\circ} \mathrm{C}+1 \mathrm{msPEF}$ of $400 \mathrm{~ms}$ at $5 \mathrm{~V} . \mathrm{cm}^{-1}$

b)

\begin{tabular}{|c|c|c|c|c|c|c|c|c|c|}
\hline & \multicolumn{3}{|c|}{$1 \mathrm{~h}$ at $4^{\circ} \mathrm{C}$ (No pulse) } & \multicolumn{3}{|c|}{$\begin{array}{l}1 \mathrm{~h} \text { at } 4^{\circ} \mathrm{C}+1 \mathrm{msPEF} \\
\text { of } 400 \mathrm{~ms} \text { at } 5 \mathrm{~V}^{-c^{-1}}\end{array}$} & \multicolumn{3}{|c|}{$\begin{array}{c}1 \mathrm{~h} \text { at } 4^{\circ} \mathrm{C}+1 \mathrm{msPEF} \text { of } \\
400 \mathrm{~ms} \text { at } 5 \mathrm{~V} \cdot \mathrm{cm}^{-1} \\
\text { followed by } 8 \mu \mathrm{sPEFs} \text { of } \\
100 \text { us at } 600 \mathrm{~V} \cdot \mathrm{cm}^{-1}\end{array}$} \\
\hline Size & Close & $\begin{array}{l}\text { Inter- } \\
\text { mediate }\end{array}$ & Far & Close & $\begin{array}{l}\text { Inter- } \\
\text { mediate }\end{array}$ & Far & Close & $\begin{array}{l}\text { Inter- } \\
\text { mediate }\end{array}$ & Far \\
\hline Large aggregates & 0,25 & 0,24 & 5,38 & 0,64 & 0,91 & 0,81 & 0,29 & 1,18 & 0,77 \\
\hline Intermediate aggregates & 0,27 & 0,47 & 4,00 & 0,15 & 0,68 & 0,40 & 0,71 & 1,16 & 0,40 \\
\hline Small aggregates & 0,34 & 1,65 & 2,47 & 0,61 & 2,39 & 1,23 & 3,52 & 2,97 & 0,98 \\
\hline NPs & 0,59 & 0,55 & 1,05 & 10,64 & 3,86 & 0,42 & 10,02 & 1,10 & 0,28 \\
\hline Total & 1,63 & 2,92 & 12,91 & 11,83 & 7,85 & 2,88 & 14,54 & 6,41 & 2,43 \\
\hline
\end{tabular}

Fig. 3: a) TEM images after the incubation of $1 \mathrm{~h}$ at $4^{\circ} \mathrm{C}$ alone (left panel) or followed by one msPEF of $400 \mathrm{~ms}$ (middle panel) or by the combination of one msPEF of $400 \mathrm{~ms}$ and the train of eight $\mu \mathrm{sPEFs}$ of $100 \mu \mathrm{s}$ (right panel). b) Number of nanoparticles per cell and per condition (size of the aggregates, distance to the cell membrane and experimental group). Large aggregates: of more than 20 GNPs; intermediate aggregates: of 10 to 20 GNPs; small aggregates: of 5 to 10 GNPs; and NPs: of one to 5 GNPs. Numbers in the table are normalized to the number of cells (in most of the images there was only one cell).

around the cells, whatever the size or distance. Second, we observed a decrease in the ratio of the number of large and intermediate aggregates to the number of small aggregates after the electric pulses delivery, specifically for the aggregates which are far from the surfaces. Third, not only the number of small aggregates or NPs increased, but also they were located closer to the membranes after the pulses delivery than in the absence of pulses delivery. The first and third observations correspond to our 
working hypothesis, the displacement of the GNPs towards the cell membrane due to pulse application. We were not expecting the reduction in the size of the GNPs (second observation) and we do not have a conclusive explanation. The forces exerted by the electric field on the large aggregates could help disassembling them, but we cannot exclude a fixation artefact. In any case, the important result is that the number of GNPs close to the membrane is largely increased after PEF application.

To ensure the absence of a permeabilization caused by one mSPEF application, clonogenic assays of cells exposed only to msPEF were performed (Fig. 4a). In the presence or not of GNPs, we found the same level of cell survival as that of the control cells (100\% of viability). Fig. $4 \mathrm{~b}$ presents the results of the clonogenic assay of cells exposed to both one msPEF and the $\mu \mathrm{sPEFs}$, combined or not with GNPs. In the absence of bleomycin, the exposure of the cell monolayer to the two types of pulses (one msPEF and the train of $\mu \mathrm{SPEFs}$ ) resulted in around $20 \%$ of cell death.

a)

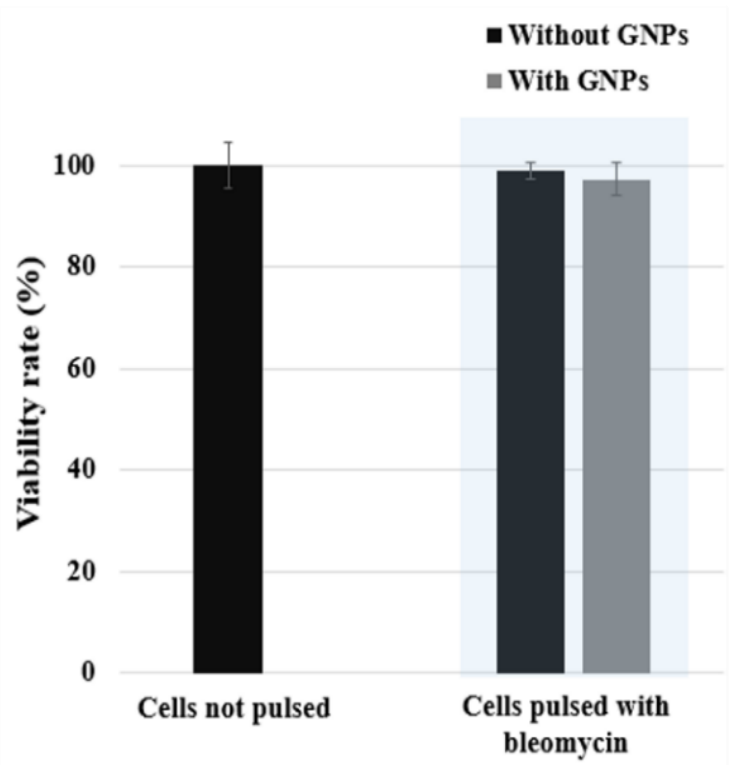

b) msPEF followed by $\mu$ sPEFs

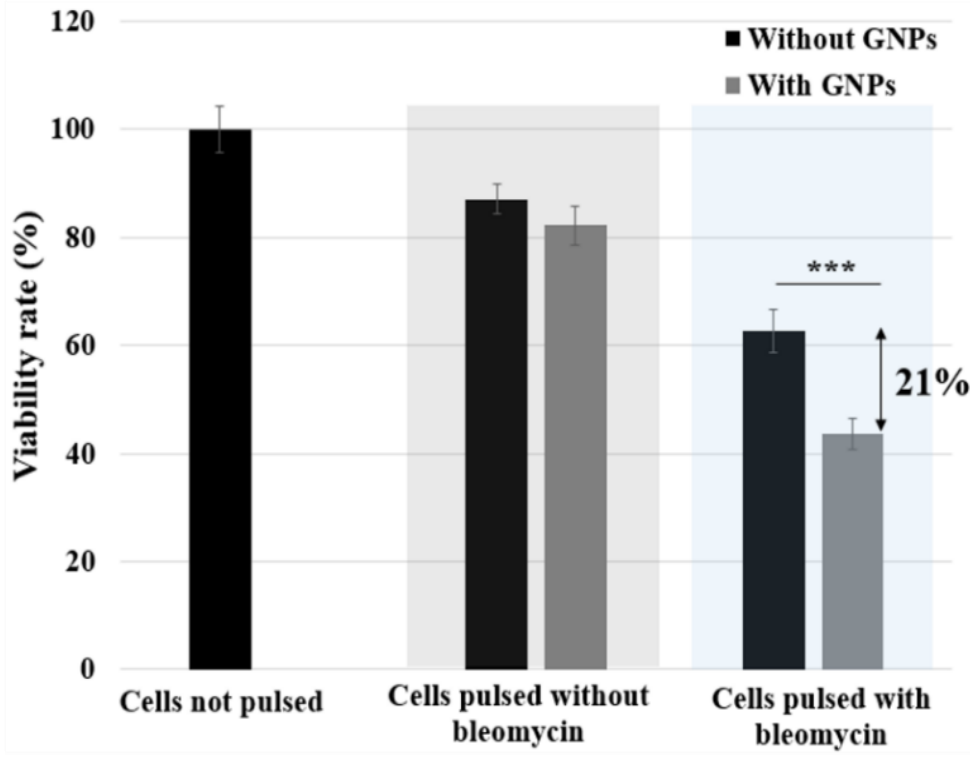

Fig. 4: a) Clonogenic assay of cells exposed to one msPEF of $400 \mathrm{~ms}$ at $5 \mathrm{~V} . \mathrm{cm}^{-1}$ applied in combination (or not) with bleomycin in the presence (or not) of GNPs after the incubation of the cells for 1 hat $4^{\circ} \mathrm{C}$. b) Clonogenic assay of cells exposed to the combination of one long one msPEF and a train of eight $\mu \mathrm{sPEFs}$ of $100 \mu \mathrm{s}$ ) applied in combination (or not) with bleomycin in the presence (or not) of GNPs after the incubation of the cells for $1 \mathrm{~h}$ at $4^{\circ} \mathrm{C}$. Results are expressed as means $\pm S D$. Experiments were performed in three independent days and each one included a triplicate for each condition. 
According to the results of Fig. 4a, we can confirm that this loss of viability was caused mainly by the uSPEFs (the second train of pulses). When bleomycin was added, the percentage of dead cells in the presence of the GNPs was significantly increased by around $21 \%$ compared to the case without GNPs. This result confirms that the application of a msPEF prior to the electroporation sequence with $\mu$ SPEFs increases the cell electropermeabilization outcome. This supports the idea that the increased number of GNPs around the cells surface resulting from the msPEF is responsible of the observed enhancement in electroporation and this could result from the local amplification of the intensity of the applied electric field due to the GNPs in contact with the cell membrane.

\subsection{Comparison of the physico-chemical characterization of GNPs and PEG-GNPs}

According to the numerical simulations performed in our previous article, isolated GNPs (the "NPs") would produce a higher EF amplification than highly aggregated GNPs. To validate experimentally this numerical result, as well as to reinforce the previous conclusions reported here above, we decided to modify the surface of GNPs to improve their stability and avoid aggregation in the working buffer (serumfree MEM culture medium). We coated GNPs with PEG (PEGylation) in order to assess the effects of the electric pulses on a population of individual nanoparticles, instead than on a population of aggregates of different sizes. After GNPs PEGylation as described in the Materials and Methods, we characterized the stability of the PEG-GNPs and non-PEGylated GNPs dispersed in serum-free MEM and compared them to GNPs dispersed in the commercial citrate buffer. Both the effective diameter and the charge were characterized (Table 1a and 1b). The GNPs in the commercial buffer displayed an effective diameter (defined as the hydrodynamic diameter) of about $50 \mathrm{~nm}$ but when the GNPs were dispersed in the serum-free MEM, an increase of the effective diameter of about $430 \mathrm{~nm}$ was observed due to the ionic content of the serum-free MEM. This increase in size confirms the presence of GNPsaggregates in the experimental medium. On the contrary, DLS measurements of PEG-GNPs, even in the serum-free MEM, displayed an average effective diameter of around $80 \mathrm{~nm}$. This slight increase, from $50 \mathrm{~nm}$ to $80 \mathrm{~nm}$, of the effective diameter between commercial (in citrate buffer) and PEGylated GNPs (in an ionic medium) could be explained by the increase of the hydrodynamic diameter caused by the PEG molecules inserted at the surface of the individual nanoparticles. Thus, we can conclude that there was very few aggregation of the PEG-GNPs in the serum-free MEM, which was not the case with the non-PEGylated GNPs. Since the polydispersity index (PDI, defined as the width of the NPs distribution in a liquid solution) in the case of PEG-GNPs and GNPs-aggregates was larger than 0.1 , we 
can confirm that these two samples could be considered as poly-disperse under our experimental conditions, with a dominant population of $80 \mathrm{~nm}$ and $430 \mathrm{~nm}$ for the PEG-GNPs and GNPs-aggregates, respectively. The zeta-potential of the PEG-GNPs $(-22.3 \mathrm{mV})$ was very similar to the zeta-potential of the GNPs-aggregates $(-20 \mathrm{mV})$. Therefore, we could anticipate that the possible electrophoretic displacement due to pulse application could still be possible in the PEG-GNPs.

a)

\begin{tabular}{|l|c|c|}
\hline & $\begin{array}{c}\text { Effective diameter } \\
\text { (nm) }\end{array}$ & $\begin{array}{c}\text { Polydispersity index } \\
\text { (PDI) }\end{array}$ \\
\hline Commercial GNPs & $50 \pm 1,5$ & 0,06 \\
\hline PEG-GNPs & $80 \pm 2$ & 0,2 \\
\hline GNPs-aggregates & $430 \pm 2,3$ & 0,18 \\
\hline
\end{tabular}

b)

\begin{tabular}{|l|c|c|}
\hline & $\begin{array}{c}\text { GNPs-aggregates } \\
(\mathbf{m V})\end{array}$ & PEG-GNPs $(\mathbf{m V})$ \\
\hline $1^{\text {st }}$ measurement & $-27,5$ & $-34,5$ \\
\hline $2^{\text {nd }}$ measurement & -18 & $-13,5$ \\
\hline $3^{\text {rd }}$ measurement & $-14,5$ & -19 \\
\hline Average of measurements & $-20 \pm 6,1$ & $-22,3 \pm 9,5$
\end{tabular}

Table 1: a) Determination of nanoparticles size by DLS measured by the intensity method; Size distribution of PEG-GNPs and GNPs-aggregates dispersed in serum-free MEM. b) Zeta potential of GNPs and PEG-GNPs. For the DLS measurement, each sample was measured 2 times and each measurement was independently repeated 3 times. For the zeta potential measurement as well, each sample was measured 2 times and each measurement was independently repeated 3 times at 3 different days.

\subsection{Pegylated GNPs and electroporation}

Subsequently, we tested the PEG-GNPs in our electroporation experiments in order to further validate if observed enhancement of the electric pulses effects by GNPs was also possible with PEG-GNPs. We first tested the effect of PEG-GNPs incubated with the cells for $3 \mathrm{~h}$ at $4^{\circ} \mathrm{C}$, an efficient condition using GNPs-aggregates as previously reported [16]. Results in Fig. 5 show that in the absence of bleomycin, the exposure of the cell monolayers to the eight $\mu$ SPEFs of $100 \mu$ s resulted in about $15 \%$ of cell death 
due to the pulse application. When bleomycin was added, a slight and non-significant increase in the electroporation efficiency was observed in the condition using PEG-GNPs compared to the condition without PEG-GNPs. This absence of effects of the PEG-GNPs can be explained by the fact that the accumulation of individual PEG-GNPs near the cells by sedimentation only (even during $3 \mathrm{~h}$ at $4^{\circ} \mathrm{C}$ ) is not efficient enough. There are at least two reasons: not only the individual nanoparticles sediment more slowly than the aggregates but also differences in the interaction NP-cell surface due to PEG coating could explain this slight effect of PEG-GNPs.

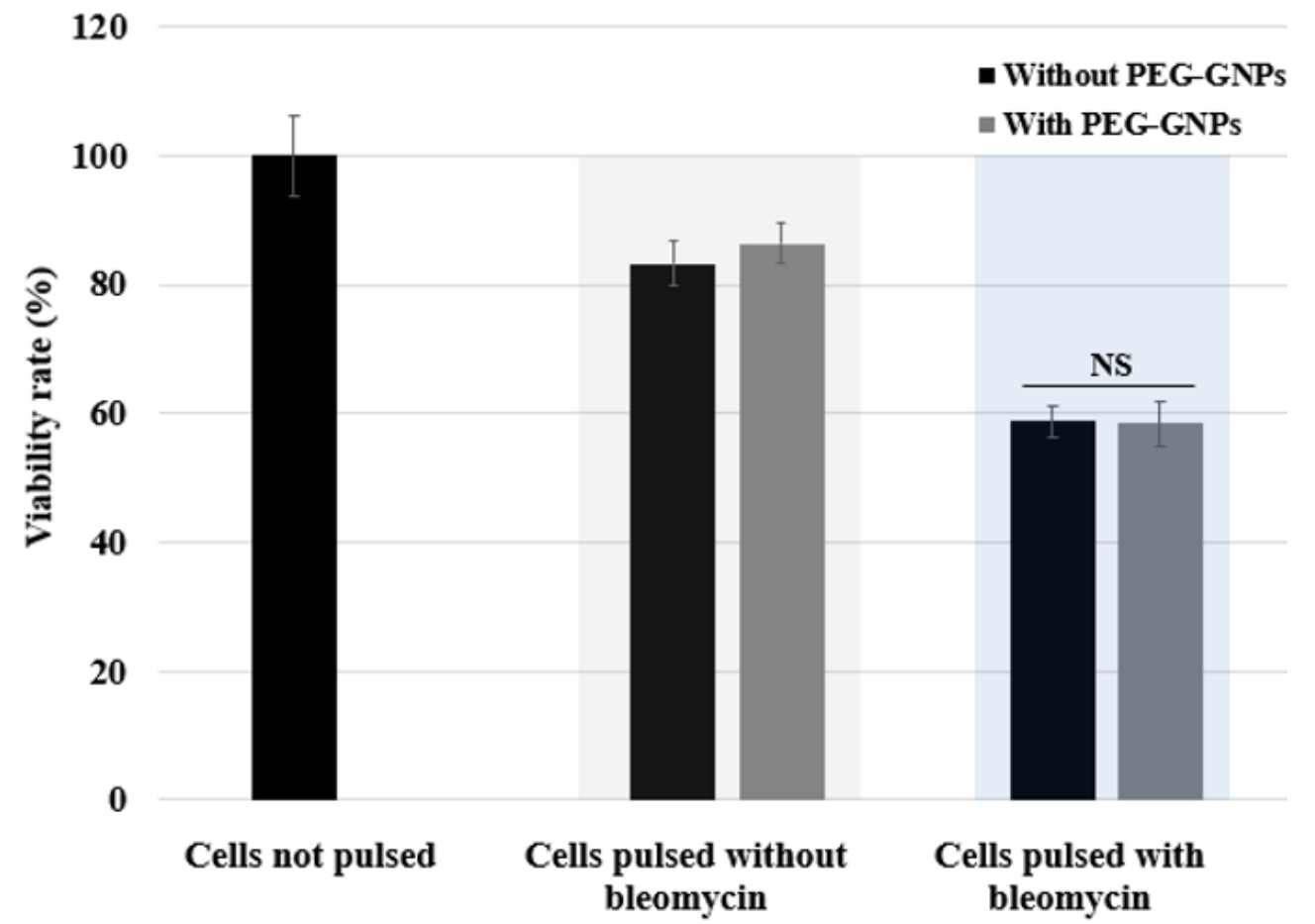

Fig. 5: Clonogenic assay: a train of eight $\mu \mathrm{sPEFs}$ of $100 \mu \mathrm{s}$ applied in combination (or not) with bleomycin in the presence of PEG-GNPs after an incubation of $3 \mathrm{~h}$ at $4{ }^{\circ} \mathrm{C}$. Results are expressed as means $\pm S D$. Experiments were performed in three independent days and each one included a triplicate for each condition.

As only the incubation of the PEG-GNPs did not show any remarkable effect on the enhancement of electroporation, we tested the possibility of using electric pulses to drive PEG-GNPs towards the cell surface. In particular, similar to the uncoated GNPs, after a short incubation of only $1 \mathrm{~h}$ at $4^{\circ} \mathrm{C}$ with the PEG-GNPs, cells were exposed to the combination of one msPEF of $400 \mathrm{~ms}$ and a train of eight $\mu$ SPEFs of $100 \mu \mathrm{s}$. In the absence of bleomycin, we observed around $15 \%$ of cell death due to the pulse application as in the previous experiments (Fig. 6c). In the presence of bleomycin, the addition of the 
PEG-GNPs significantly decreased the viability rate caused by electroporation by around $22 \%$. As reported above, this increase in the efficacy of the $\mu$ SPEFs was not observed with just a long incubation of $3 \mathrm{~h}$ at $4^{\circ} \mathrm{C}$.

Representative TEM images of cells exposed to one msPEF (Fig. 6a) or to the combination of one msPEF and a train of eight $\mu$ sPEFs (Fig. $6 \mathrm{~b}$ ) after the incubation of $1 \mathrm{~h}$ at $4^{\circ} \mathrm{C}$ with the PEG-GNPs confirmed the accumulation of individual nanoparticles around the cell membrane. It is worth mentioning that TEM images of cells incubated for $3 \mathrm{~h}$ at $4^{\circ} \mathrm{C}$ with the PEG-GNPs but not exposed to pulses did not show any GNP nearby the cell membrane, which is in agreement with the observed results (data not shown). This indicates again that electric pulses have an active role in improving the accumulation of PEG-GNPs at the cell surface. Compared to observations made with non-PEGylated GNPs there is a considerably lower number of PEG-GNPs around the cells. This could be explained by a weaker interaction of PEG-GNPs with the cell surface and also the possible loss of NPs at the time of the cells fixation. However, those that are observed in the TEM images are very close to the membrane, what could be enough to produce a localized amplification of the electric field and thus an increased electroporation effect. 
a) Single msPEF

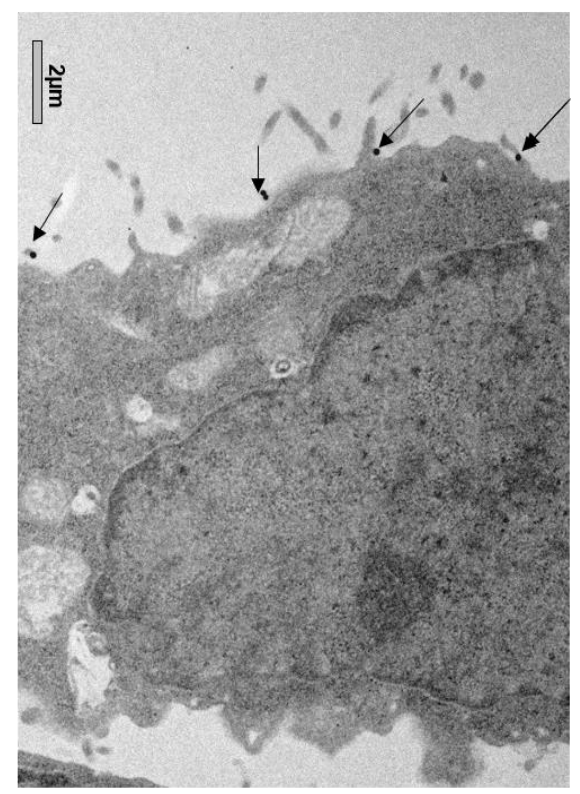

c)

msPEF followed by $\mu$ sPEFs

$(50 \mu \mathrm{g} / \mathrm{ml})$

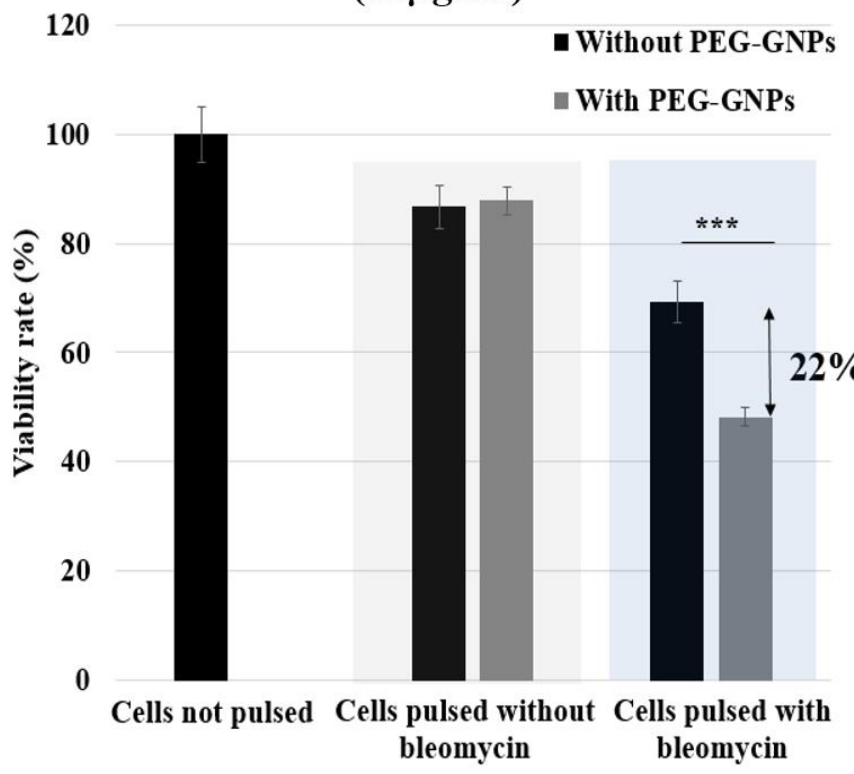

b) Single msPEF+ 8usPEFs

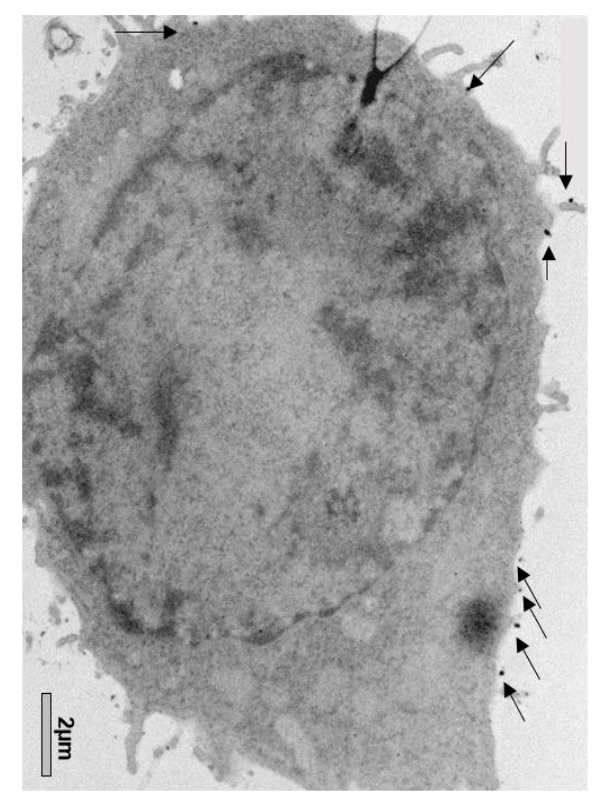

d) msPEF followed by $\mu$ sEFs $(100 \mu \mathrm{g} / \mathrm{ml})$

120

— Without PEG-GNPs

- With PEG-GNPs

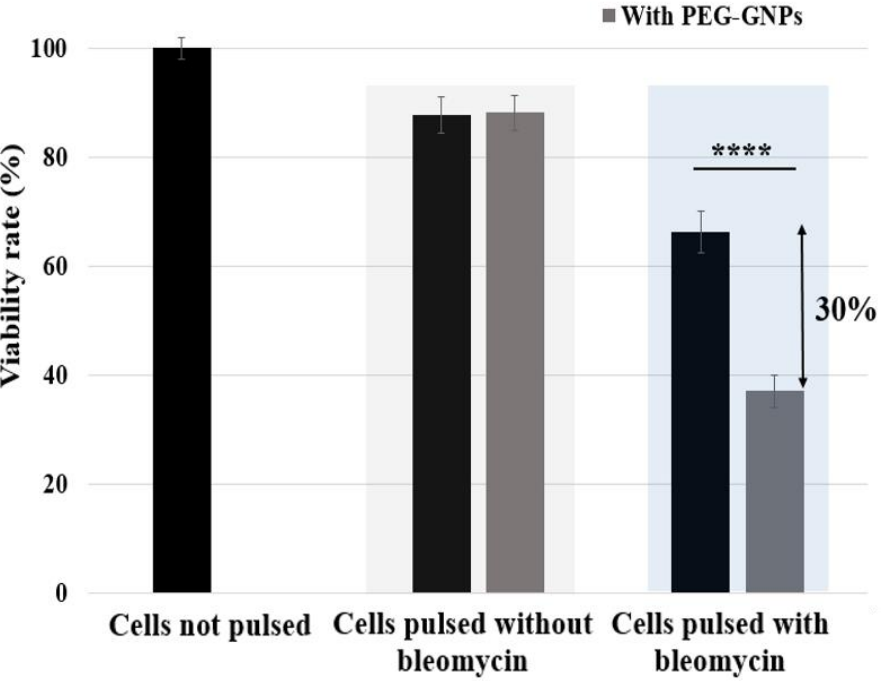

Fig. 6: a) TEM representative image of cells incubated with PEG-GNPs during 1 hour at $4^{\circ} \mathrm{C}$ and then exposed to one msPEF; b) TEM representative image of cells incubated with PEG-GNPs during $1 \mathrm{~h}$ at $4^{\circ} \mathrm{C}$ and then exposed to one msPEF of $400 \mathrm{~ms}$ and a train of eight $\mu \mathrm{sPEFs}$ of $100 \mu \mathrm{s}$; c) Clonogenic assay of cells exposed to a combination of one msPEF and a train of eight $\mu \mathrm{sPEFs}$ of $100 \mu$ s applied in combination (or not) with bleomycin in the presence (or not) of PEG-GNPs $\left(50 \mathrm{mg}^{-\mathrm{ml}^{-1}}\right)$ previously incubated with the cells for $1 \mathrm{~h}$ at $4{ }^{\circ} \mathrm{C}$; d) Clonogenic assay of cells exposed to a combination of one msPEF of $400 \mathrm{~ms}$ and a train of eight $\mu \mathrm{sPEFs}$ of $100 \mu \mathrm{s}$ applied in combination (or not) with bleomycin in the presence (or not) of PEG-GNPs at $100 \mu \mathrm{g} \cdot \mathrm{ml}^{-1}$ incubated with the cells for $1 \mathrm{~h}$ at $4^{\circ} \mathrm{C}$. Results are expressed as means $\pm S D$. Experiments were performed in three independent days and each one included a triplicate for each condition. 
Finally, to further increase the number of PEG-GNPs at the cell surface, we tested the increase of the PEG-GNPs concentration, from $50 \mu \mathrm{g} \cdot \mathrm{ml}^{-1}$ to $100 \mu \mathrm{g} \cdot \mathrm{ml}^{-1}$, alone or combined to the electric pulses (msPEF followed by $\mu$ SPEFs) (Fig. 6d). In the absence of bleomycin we observed again the same percentage of cell death (around $15 \%$ ) due to the electric pulses, independently of the presence or not of the PEG-GNPs. Therefore, the increase of the PEG-GNPs concentration did not result in any toxic effect. In the presence of bleomycin, the addition of PEG-GNPs at a concentration of $100 \mu \mathrm{g} \cdot \mathrm{ml}^{-1}$ significantly increased the permeabilization effect by around $30 \%$. Additionally, compared to the case of PEG-GNPs at $50 \mu \mathrm{g} \cdot \mathrm{ml}^{-1}$, the msPEF increased the efficacy of the $\mu \mathrm{sPEFs}$ from $22 \%$ to $30 \%$ reinforcing the idea that the increase in the efficacy of the $\mu$ SPEFs is linked to the local accumulation of PEG-GNPs near the membrane of the cells.

\section{Discussion}

Encouraged by our previously published results and the observation presented in the first part of the results section from the electron microscopy images, the present work aimed at the further enhancement of cell electroporation caused by the addition of conductive nanoparticles. The relevant observation at the origin of the present study was performed on TEM images of cells incubated with GNPs and exposed to a train of eight classical electropermeabilizing $\mu \mathrm{sPEFs}$ of a duration of $100 \mu \mathrm{s}$ : the number of GNPs near the membrane seemed higher than in the absence of the electric pulses.

In the present study we tried not only to optimize the potentiation of the $\mu$ SPEF by the addition of GNPs, but also to overcome the necessity of a long incubation approach. Indeed, in our previous work, a long incubation (for $3 \mathrm{~h}$ ) produced a statistically significant increase of the $\mu$ SPEF efficacy, while the short incubations (for $1 \mathrm{~h}$ ) produced only a non-significant tendency. We supposed that the physical contact between the cells and the nanoparticles (or their presence in the immediate neighbourhood of the cells) was essential to generate an increase of the cell electroporation. According to this hypothesis, nonlocalized effects of the GNPs, such as a change in the medium conductivity, should not be instrumental in the achievement of the effects of the conductive NPs here reported. Actually, we observed different permeabilization levels with and without the GNPs even though the addition of the GNPs (at least at the concentrations used in our experiments) did not change the medium conductivity. The hypothesis here above was validated in silico by the numerical calculations reported in our previous article, which showed that the conductive nanoparticles locally modify the electric field applied and lead to an amplification of 
the local electric field at the cell membrane. This in silico work teaches us two things. First, the closer are the particles to the membrane, the higher the electric filed effects on the membrane. Second, isolated particles should be more efficient than large aggregates. Then, when isolated particles are located very close to the cell membrane, this local amplification of the electric field is sufficient to enhance the transmembrane voltage, locally, and to favour the membrane electroporation at the places located near the nanoparticles.

To ameliorate the placement of the conductive nanoparticles near the surface of the membrane, we sought at a method less time-consuming than the sedimentation, and that could be used not only in vitro but in vivo as well. Based on the observation recalled here above, we thus explored whether the long sedimentation could be replaced by an electric pulse driven accumulation of conductive GNPs (and the aggregates of GNPs) at the surface of the cell. The most plausible mechanism for this is electrophoresis. Indeed, the electrophoresis of charged GNPs was already proved in previous reports $[33,34]$ where authors showed that the displacement of GNPs under electrophoretic forces is especially related to the size, shape and the electrolyte solution (notably the ionic strength of the medium). The displacement of charged GNPs under electrophoretic forces was used in previous studies for several purposes as, for example, for the thorough understanding of particle surface charge or for biomedical applications[33,34]. In the present study, we found conditions (one long msPEF of $400 \mathrm{~ms}$ duration at an amplitude of 5 V.cm-1) that did not electroporate the cells by themselves, while being able to bring the GNPs close to the cell surface (as shown by TEM). These conditions were found as efficient as the long incubations of $3 \mathrm{~h}$ at $4^{\circ} \mathrm{C}$ used in our previous article and showed similar results in the improvement of the cell permeabilization efficiency. This result confirms that the efficacy of the train of $\mu \mathrm{sPEFs}$ to permeabilize the membrane was actually improved if the NPs are in contact with (or very close to) the cell membrane, which is obtained by the first msPEF application.

The TEM images not only confirmed that the GNPs were located closer to the membranes after the electric pulses application, but moreover allowed to make another surprising observation. The ratio of isolated nanoparticles or very small aggregates (less than 5 nanoparticles) close to the membrane increased with respect to the other sizes of aggregates after the delivery of the electric pulse(s). Maybe this is merely the consequence of a lower loss of the aggregates than the loss of the isolated nanoparticles at the time of the cells fixation, particularly for the isolated particles located far from the 
membrane that would be massively lost. However, we cannot exclude another hypothetical explanation that could be linked to a more complex interaction of the electric fields and the aggregates, if the electric fields could cause the destabilisation of the large aggregates and thus their transformation in a larger number of isolated nanoparticles or small aggregates. We did not test these hypotheses, but we wondered whether we could increase the efficacy of the nanoparticles under conditions where most of the nanoparticles could remain isolated.

To this end, we decided to PEGylate the GNPs because it was known that the PEGylation of the conductive nanoparticles results in the generation of repulsive forces at the surface of the nanoparticles that prevent their aggregation. Using DLS measurements, we verified that after PEGylation, mostly (but not only) individual nanoparticles were present in an ionic medium such as the serum-free MEM.

In the absence of electric pulses, the addition of the PEG-GNPs did not result in a significant increase of the permeabilizing efficacy of the $\mu$ SPEFs. We supposed that this was linked to the fact that aggregates sediment faster and better than the isolated nanoparticles.

Since the zeta potential of the PEG-GNPs was comparable to the zeta potential of the GNPs aggregates, we anticipated that we could use the electrophoretic msPEF to bring the PEG-GNPs close to the cells. Moreover, several studies had shown that the smaller the size of the nanoparticles is, the faster the rate of migration is [35]. However, according to Patra et al [32], polymer coated GNPs (i.e PEG) should decrease the total electrophoretic force (due to an increase of the electrophoretic retardation force). Although the PEG chains could decrease the zeta-potential of naked GNPs, our data show that the PEG-GNPs are still negatively charged and therefore could be considered as capable of being moved by the electrophoretic pulse. This hypothesis was supported by the increased effectivity of PEG-GNPs after the use of the electrophoretic mSPEF providing results comparable to the increase caused by a 3 hincubation of the GNPs aggregates.

Therefore, all our results confirm that the local enhancement of the electric field by conductive nanoparticles is mainly associated to the number of conductive NPs and specifically to their close distance with respect to the surfaces of the cell membrane. This amplification of the effect of the electric field was observed not only in the presence of aggregates of conductive NPs but also in the presence of PEG-GNPs (which are present in the medium mainly as isolated single NPs). The electrophoretic pulse(s) must be performed before the electroporative pulses. This is an important point to highlight, 
based on our mechanistic study. Indeed, combination of electroporative pulses (termed HV) and electrophoretic pulses (termed LV) have been already applied, mainly in vivo, for a large and reproducible electrotransfer of nucleic acids in tissues such as muscle or skin $[22,23]$. In all these studies, the HV pulses, that affect the cell membrane, have to be delivered before the LV pulses, that displace the charged molecules across the extracellular matrix and also across the plasma membrane)[18]. This combination facilitates the penetration of charged molecules into the cytosol, even for very large molecules such as long coding nucleic acids. Here, the goal is not the introduction of the nanoparticles inside the cells. Indeed, the pulses seek first to displace the conductive nanoparticles towards the surface of cells using a non-permeabilizing pulse (LV) and secondly to facilitate cell electropermeabilization using an already electroporative pulse (HV) whose effects will be locally enhanced due to the presence of conductive NPs at the surface of the cells.

Finally, to reinforce the mechanism of the local reinforcement of the electric pulses due to the presence of the conductive nanoparticles at the cell surface before the delivery of the electroporative pulses, we showed the influence of the concentration of the nanoparticles. When the concentration was doubled and the nanoparticles electrophoretically approached to the cell membrane by one msPEF, the increase of the efficacy of the train of eight electroporative $\mu \mathrm{SPEFs}$ reached $30 \%$.

\section{Conclusion}

To the best of our knowledge, this study represents the first application of electrophoretic forces on conductive NPs, either isolated (i.e PEG-GNPs) or in aggregates, in order to displace them towards the cell surface for cell electroporation improvement. This approach permitted the decrease of the incubation time of the NPs with cells while keeping a good interaction of GNPs-cell membrane. Indeed, we achieved the same improvement of the electroporation efficiency than the $3 \mathrm{~h}$-long incubation reported in our previous work [16]. The increased presence of the nanoparticles near the cell membrane after electric field exposure was corroborated by TEM. Surface modification of GNPs by PEGylation enabled to produce stable solutions of mostly isolated NPs in culture medium. The results confirmed that isolated PEG-GNPs can be electrophoretically driven towards the cell membrane and improve the efficiency of electroporation pulses. The increase of the nanoparticles concentration further increased the improvement of the electroporation efficiency. The data here reported, which evidence the importance of the accumulation of the nanoparticles close to, or in contact with, the cell membrane to achieve an 
enhancement of the local EF, confirm the role of conductive NPs as local nanoamplifiers of an externally applied EF as modelled in our previous publication [16].

These data could enable us to translate our in vitro studies to in vivo, where the electrophoretic pulses would act to improve the interaction of the NPs with the target cells (long incubations would not be possible in vivo). The double pulse approach combined to the local NPs injection should allow a reduction of the external EF intensity required to achieve in vivo effective cell electropermeabilization.

\section{Aknowledgements}

We acknowledge Sylvie Souquere from "Plateforme de microscopie electronique cellulaire", UMS 3655 AMMICa, who acquired the TEM images, Dr. Jean-Remi Bertrand and Dr. Giorgia Urbinati who provided insight and expertise in the DLS measurements.

\section{Funding}

This work was partially funded by La Ligue contre le Cancer postdoctoral fellowship program to TGS and a grant of Tunisian government to AG. The authors thank the funding support of the CNRS, Gustave Roussy, Univ. Paris-Sud and Université Paris-Saclay, as well as the ITMO Cancer in the frame of the Plan Cancer 2015-2019 (project PC201517).

\section{References}

[1] S. Gelperina, K. Kisich, M.D. Iseman, L. Heifets, The potential advantages of nanoparticle drug delivery systems in chemotherapy of tuberculosis, Am. J. Respir. Crit. Care Med. 172 (2005) 1487-1490. https://doi.org/10.1164/rccm.200504-613PP.

[2] V. V. Mody, A. Cox, S. Shah, A. Singh, W. Bevins, H. Parihar, Magnetic nanoparticle drug delivery systems for targeting tumor, Appl. Nanosci. 4 (2014) 385-392. https://doi.org/10.1007/s13204-013-0216-y.

[3] R. Singh, J.W. Lillard, Nanoparticle-based targeted drug delivery, Exp. Mol. Pathol. 86 (2009) 215-223. https://doi.org/10.1016/j.yexmp.2008.12.004.

[4] N.R. Popova, A.L. Popov, A.B. Shcherbakov, V.K. Ivanov, Layer-by-layer capsules as smart delivery systems of $\mathrm{CeO} 2$ nanoparticle-based theranostic agents, Nanosyst. Physics, Chem. Math. 8 (2017) 282-289. https://doi.org/10.17586/2220-8054-2017-8-2-282-289.

[5] J. Xie, S. Lee, X. Chen, Nanoparticle-based theranostic agents, Adv. Drug Deliv. Rev. 62 (2010) 1064-1079. https://doi.org/10.1016/j.addr.2010.07.009.

[6] S. Jafari, H. Derakhshankhah, L. Alaei, A. Fattahi, B.S. Varnamkhasti, A.A. Saboury, Mesoporous silica nanoparticles for therapeutic/diagnostic applications, Biomed. Pharmacother. 109 (2019) 1100-1111. https://doi.org/10.1016/j.biopha.2018.10.167.

[7] S.K. Nune, P. Gunda, P.K. Thallapally, Y.Y. Lin, M. Laird Forrest, C.J. Berkland, Nanoparticles for biomedical imaging, Expert Opin. Drug Deliv. 6 (2009) 1175-1194. https://doi.org/10.1517/17425240903229031.

[8] X. Du, X. Li, L. Xiong, X. Zhang, F. Kleitz, S.Z. Qiao, Mesoporous silica nanoparticles with organo-bridged silsesquioxane framework as innovative platforms for bioimaging and therapeutic agent delivery, Biomaterials. 91 (2016) 90-127. 
https://doi.org/10.1016/j.biomaterials.2016.03.019.

[9] Y. Malam, M. Loizidou, A.M. Seifalian, Liposomes and nanoparticles: nanosized vehicles for drug delivery in cancer, Trends Pharmacol. Sci. 30 (2009) 592-599.

https://doi.org/10.1016/j.tips.2009.08.004.

[10] I.I. Slowing, J.L. Vivero-Escoto, C.W. Wu, V.S.Y. Lin, Mesoporous silica nanoparticles as controlled release drug delivery and gene transfection carriers, Adv. Drug Deliv. Rev. 60 (2008) 1278-1288. https://doi.org/10.1016/j.addr.2008.03.012.

[11] M. ElMahmoudy, V.F. Curto, M. Ferro, A. Hama, G.G. Malliaras, R.P. O'Connor, S. Sanaur, Electrically controlled cellular migration on a periodically micropatterned PEDOT:PSS conducting polymer platform, J. Appl. Polym. Sci. 136 (2019) 47029. https://doi.org/10.1002/app.47029.

[12] M.M. Mahan, A.L. Doiron, Gold Nanoparticles as X-Ray, CT, and Multimodal Imaging Contrast Agents: Formulation, Targeting, and Methodology, J. Nanomater. 2018 (2018). https://doi.org/10.1155/2018/5837276.

[13] J.F. Hainfeld, D.N. Slatkin, H.M. Smilowitz, The use of gold nanoparticles to enhance radiotherapy in mice, Phys. Med. Biol. 49 (2004) N309-15. https://doi.org/10.1088/00319155/49/18/N03.

[14] A.M. Gobin, E.M. Watkins, E. Quevedo, V.L. Colvin, J.L. West, Near-infrared-resonant gold/gold sulfide nanoparticles as a photothermal cancer therapeutic agent, Small. 6 (2010) 745-752. https://doi.org/10.1002/smll.200901557.

[15] E.E. Connor, J. Mwamuka, A. Gole, C.J. Murphy, M.D. Wyatt, Gold nanoparticles are taken up by human cells but do not cause acute cytotoxicity, Small. 1 (2005) 325-327. https://doi.org/10.1002/smll.200400093.

[16] A. Ghorbel, L.M. Mir, T. García-Sánchez, Conductive nanoparticles improve cell electropermeabilization., Nanotechnology. 30 (2019) 495101. https://doi.org/10.1088/13616528/ab3be9.

[17] E. Neumann, M. Schaefer-Ridder, Y. Wang, P.H. Hofschneider, Gene transfer into mouse lyoma cells by electroporation in high electric fields., EMBO J. 1 (1982) 841-845. https://doi.org/10.1002/j.1460-2075.1982.tb01257.x.

[18] A. Azan, F. Gailliègue, L.M. Mir, M. Breton, Cell membrane electropulsation: Chemical analysis of cell membrane modifications and associated transport mechanisms, in: Adv. Anat. Embryol. Cell Biol., Springer Verlag, 2017: pp. 59-71. https://doi.org/10.1007/978-3-319-56895-9_4.

[19] L.M. Mir, H. Banoun, C. Paoletti, Introduction of definite amounts of nonpermeant molecules into living cells after electropermeabilization: Direct access to the cytosol, Exp. Cell Res. 175 (1988) 15-25. https://doi.org/10.1016/0014-4827(88)90251-0.

[20] A. Gothelf, L.M. Mir, J. Gehl, Electrochemotherapy: Results of cancer treatment using enhanced delivery of bleomycin by electroporation, Cancer Treat. Rev. 29 (2003) 371-387. https://doi.org/10.1016/S0305-7372(03)00073-2.

[21] M. Kandušer, D. Miklavčič, M. Pavlin, Mechanisms involved in gene electrotransfer using highand low-voltage pulses - An in vitro study, Bioelectrochemistry. 74 (2009) 265-271. https://doi.org/10.1016/j.bioelechem.2008.09.002.

[22] F. André, J. Gehl, G. Sersa, V. Préat, P. Hojman, J. Eriksen, M. Golzio, M. Cemazar, N. Pavselj, M.-P. Rols, F.M. André, J. Gehl, G. Sersa, V. Préat, P. Hojman, J. Eriksen, M. Golzio, M. Cemazar, N. Pavselj, M.-P. Rols, D. Miklavcic, E. Neumann, J. Teissié, L.M. Mir, Efficiency of high-and low-voltage pulse combinations for gene electrotransfer in muscle, liver, tumor, and skin. Efficiency of High-and Low-Voltage Pulse Combinations for Gene Electrotransfer in Muscle, Liver, Tumor, and Skin, Hum. Gene Ther. 19 (2008) 1261-1271. https://doi.org/10.1089/hgt.2008.060ï.

[23] S. Šatkauskas, F. André, M.F. Bureau, D. Scherman, D. Miklavčič, L.M. Mir, Electrophoretic component of electric pulses determines the efficacy of in vivo DNA electrotransfer, Hum. Gene Ther. 16 (2005) 1194-1201. https://doi.org/10.1089/hum.2005.16.1194.

[24] V. Raffa, C. Riggio, M.W. Smith, K.C. Jordan, W. Cao, A. Cuschieri, BNNT-Mediated Irreversible Electroporation: Its Potential on Cancer Cells, Technol. Cancer Res. Treat. 11 (2012) 459-465. https://doi.org/10.7785/tcrt.2012.500258.

[25] V. Raffa, G. Ciofani, A. Cuschieri, Enhanced low voltage cell electropermeabilization by boron nitride nanotubes, Nanotechnology. 20 (2009) 075104. https://doi.org/10.1088/09574484/20/7/075104.

[26] S. Huang, H. Deshmukh, K.K. Rajagopalan, S. Wang, Gold nanoparticles electroporation enhanced polyplex delivery to mammalian cells, Electrophoresis. 35 (2014) 1837-1845. https://doi.org/10.1002/elps.201300617. 
[27] Y. Zu, S. Huang, W.C. Liao, Y. Lu, S. Wang, Gold nanoparticles enhanced electroporation for mammalian cell transfection, J. Biomed. Nanotechnol. 10 (2014) 982-992. https://doi.org/10.1166/jbn.2014.1797.

[28] K. Rahme, L. Chen, R.G. Hobbs, M.A. Morris, C. O'Driscoll, J.D. Holmes, PEGylated gold nanoparticles: Polymer quantification as a function of PEG lengths and nanoparticle dimensions, RSC Adv. 3 (2013) 6085-6094. https://doi.org/10.1039/c3ra22739a.

[29] T.A. Larson, P.P. Joshi, K. Sokolov, Preventing protein adsorption and macrophage uptake of gold nanoparticles via a hydrophobic shield, ACS Nano. 6 (2012) 9182-9190. https://doi.org/10.1021/nn3035155.

[30] Y. Liu, M.K. Shipton, J. Ryan, E.D. Kaufman, S. Franzen, D.L. Feldheim, Synthesis, stability, and cellular internalization of gold nanoparticles containing mixed peptide-poly(ethylene glycol) monolayers, Anal. Chem. 79 (2007) 2221-2229. https://doi.org/10.1021/ac061578f.

[31] O.N. Pakhomova, B.W. Gregory, V.A. Khorokhorina, A.M. Bowman, S. Xiao, A.G. Pakhomov, Electroporation-induced electrosensitization, PLoS One. 6 (2011) e0159434. https://doi.org/10.1371/journal.pone.0017100.

[32] A. Silve, A. Guimerà Brunet, B. Al-Sakere, A. Ivorra, L.M. Mir, Comparison of the effects of the repetition rate between microsecond and nanosecond pulses: Electropermeabilization-induced electro-desensitization?, Biochim. Biophys. Acta - Gen. Subj. 1840 (2014) 2139-2151. https://doi.org/10.1016/j.bbagen.2014.02.011.

[33] H.K. Patra, D. GuhaSarkar, A.K. Dasgupta, Multimodal electrophoresis of gold nanoparticles: A real time approach, Anal. Chim. Acta. 649 (2009) 128-134. https://doi.org/10.1016/j.aca.2009.07.012.

[34] C. Pfeiffer, C. Rehbock, D. Hühn, C. Carrillo-Carrion, D.J. De Aberasturi, V. Merk, S. Barcikowski, W.J. Parak, Interaction of colloidal nanoparticles with their local environment: The (ionic) nanoenvironment around nanoparticles is different from bulk and determines the physico-chemical properties of the nanoparticles, J. R. Soc. Interface. 11 (2014) 20130931. https://doi.org/10.1098/rsif.2013.0931.

[35] S. Movahed, D. Li, Electrokinetic transport of nanoparticles to opening of nanopores on cell membrane during electroporation, J. Nanoparticle Res. 15 (2013) 1511.

https://doi.org/10.1007/s11051-013-1511-y. 